\title{
Pengaruh Perbedaan Varietas terhadap Profil Tanaman Sorghum Green Fodder yang Ditanam Secara Hidroponik
}

\author{
Teguh Wahyono ${ }^{1 *}$, Dede Sukandar ${ }^{2}$, Rista Kurnia Dewi ${ }^{2}$, \\ Widhi Kurniawan ${ }^{3}$, Sihono ${ }^{1}$ \\ ${ }^{1}$ Pusat Aplikasi Isotop dan Radiasi, Badan Tenaga Nuklir Nasional \\ Jl. Lebak Bulus Raya No. 49, Cilandak, Jakarta Selatan 12070 \\ ${ }^{2}$ Fakultas Sains dan Teknologi, Universitas Islam Negeri Syarif Hidayatullah \\ Jl. Ir. H. Juanda No. 95, Ciputat, Banten \\ ${ }^{3}$ Fakultas Peternakan, Universitas Halu Oleo \\ Jl. H.E.A. Mokodompit Kampus Hijau Bumi Tridharma, Anduonohu, Kendari 93232 \\ *Email korespondensi: teguhwahyono@batan.go.id
}

(Diterima 02-02-2020; disetujui 28-04-2020)

\begin{abstract}
ABSTRAK
Teknik hidroponik adalah salah satu metode alternatif dalam budidaya hijauan pakan. Tanaman sorgum telah dikembangkan di Indonesia sebagai alternatif penyedia hijauan pakan. Badan Tenaga Nuklir Nasional (BATAN) telah menghasilkan tiga varietas sorgum berupa varietas Pahat (P), Samurai 1 (S1) dan Samurai 2 (S2). Ketiga varietas ini dapat dikembangkan sebagai Sorghum Green Fodder (SGF). Tujuan dari penelitian ini adalah untuk mengetahui profil pertumbuhan, nutrien dan kecernaan SGF dari tiga varietas sorgum yang berbeda yang ditanam secara hidroponik. Perlakuan penelitian pada studi profil pertumbuhan dan nutrisi adalah: 1) P sebagai varietas kontrol; 2) S1 dan 3) S2. Perlakuan pada studi kecernaan in vitro adalah: 1) RL (rumput lapangan); 2) P; 3) S1 dan 4) S2. Penelitian ini menggunakan rancangan acak lengkap (RAL) dengan lima ulangan. Hasil penelitian menunjukkan bahwa Samurai 2 menghasilkan SGF dengan tinggi tanaman dan berat panen segar tertinggi $(\mathrm{P}<0,05)$. SGF Samurai 1 mengandung protein kasar tertinggi yaitu $19,26 \%$. Kandungan neutral detergent fiber (NDF) SGF ketiga varietas tidak berbeda nyata. SGF varietas Pahat menghasilkan estimasi RFV tertinggi $(\mathrm{P}<0,05)$. Nilai kecernaan bahan kering $(\mathrm{BK})$ dan bahan organik (BO) SGF lebih tinggi dibandingkan rumput lapangan $(\mathrm{P}<0,05)$. Kesimpulan dari penelitian ini adalah SGF Samurai 2 menghasilkan produksi biomassa tertinggi. Kecernaan in vitro SGF varietas Pahat lebih tinggi dibandingkan kedua varietas lain dan rumput lapangan.
\end{abstract}

Kata kunci: Hidroponik, Kecernaan In vitro, Profil nutrisi, Relative feed value, Sorghum green fodder

\begin{abstract}
Hydroponics technique is one of an alternative method for forage cultivation. Sorghum has been developed in Indonesia as an alternative forage. Indonesia National Nuclear Energy Agency (BATAN) has produced three varieties of sorghum (Pahat, Samurai 1 and Samurai 2). These three varieties can develop as Sorghum Green Fodder (SGF). The purpose of this study was to investigate the growth, nutrient and digestibility profile of SGF from three different sorghum varieties. The treatment of the studies were: 1) P (Pahat) as control; 2) S1 (Samurai 1); 3) S2 (Samurai 2). Treatment on In vitro digestibility study: 1) RL (native grass); 2) P; 3) S1 and 4) S2. Complete randomized design with five replications was use in this study. The results showed that Samurai 2 produced the highest height and fresh weight $(21.35 \mathrm{~cm}$ and $1.20 \mathrm{~kg})(\mathrm{P}<0.05)$. Neutral detergent fiber (NDF) of three varieties SGF was not significantly different. The highest relative feed value (RFV) was produced by SGF from Pahat variety. Dry matter (DM) and organic matter (OM) digestibility of SGF is higher than field grass $(\mathrm{P}<0,05)$. The conclusion of this research is SGF Samurai 2 produces the highest biomass production compared to Pahat and Samurai 1 varieties. In vitro digestibility of SGF from Pahat variety is better than other varieties and native grass.
\end{abstract}

Keywords: hidroponics, in vitro digestibility, nutrient profile, relative feed value, sorghum green fodder 


\section{PENDAHULUAN}

Sektor peternakan adalah salah satu sektor yang menjadi prioritas dalam percepatan menuju kedaulatan pangan. Hal tersebut menjadi dasar perlunya percepatan teknologi dalam pengembangannya. Berbagai tantangan harus dihadapi terutama dalam penyediaan hijauan pakan bagi ternak ruminansia. Ketersediaan lahan hijauan pakan merupakan masalah klasik yang harus diatasi. Budiarsana et al. (2009) melaporkan bahwa lokasi perkembangan peternakan dan pertanian banyak dipengaruhi oleh lahan yang bersifat dinamis. Dinamika yang dimaksud adalah adanya alih fungsi lahan yang masif. Sumanto \& Juarini (2004) melaporkan bahwa dalam perkembangan kemajuan Iptek, pembangunan fisik dan tekanan penduduk, perencanaan penggunaan lahan merupakan suatu keharusan untuk semua kegiatan khususnya sektor peternakan. Perencanaan yang dimaksud adalah penerapan teknologi dalam produksi hijuan pakan di lahan yang semakin terbatas.

Produksi hijauan pakan di lahan terbatas dapat dilakukan menggunakan teknik hidroponik. Nugroho et al. (2015) melaporkan bahwa teknik hidroponic fodder adalah teknik budidaya tanaman pakan yang menggunakan media cair untuk pertumbuhannya. Hal tersebut dapat meminimalisir berbagai kendala yang berhubungan dengan penyediaan tanah/lahan. Kelebihan dari teknik ini adalah tidak memerlukan lahan yang luas, waktu panen yang relatif singkat dan palatabilitas hijauan yang tinggi. Berbagai penelitian hydroponic fodder telah dilakukan menggunakan berbagai materi tanaman diantaranya: barley (Ghazi et al., 2011; Akbag et al., 2014; Saidi \& Omar, 2015), jagung (Nugroho et al., 2015), kacang hijau (Zahera et al., 2015), oats, wheat dan tanaman serealia lain (Fazaeli et al., 2012).

Komoditas tanaman serealia yang potensial dikembangkan di Indonesia sebagai Hydroponic fodder adalah sorgum. Tanaman ini cocok dikembangkan di Indonesia dan telah berkembang sebagai alternatif penyedia hijauan pakan. Badan Tenaga Nuklir Nasional (BATAN) telah menghasilkan 3 varietas sorgum yang memiliki keunggulan produksi biomassa tinggi dan kandungan nutrisi yang baik (Sihono et al., 2013). Ketiga varietas tersebut adalah varietas Pahat, Samurai 1 dan Samurai 2. Kedua varietas terakhir adalah hasil mutasi radiasi dari indukan varietas Pahat. Ketiga varietas ini belum dimanfaatkan secara optimal sebagai sumber hijauan pakan sehingga perlu dikembangkan sebagai Sorghum Green Fodder (SGF). Sampai saat ini belum ada studi yang mendalami profil nutrisi SGF sebagai hijauan pakan ruminansia. Hal tersebut merupakan dasar perlunya kajian ilmiah untuk mengawalinya. Tujuan dari penelitian ini adalah untuk mengevaluasi profil pertumbuhan, nutrien dan kecernaan SGF dari tiga varietas sorgum yang berbeda yang ditanam secara hidroponik.

\section{MATERI DAN METODE}

\section{Persiapan Bahan}

Bahan yang digunakan pada penelitian ini meliputi biji sorgum varietas Pahat, Samurai 1, dan Samurai 2. Ketiga varietas biji sorgum diperoleh dari laboratorium Pemuliaan Tanaman, Bidang Pertanian, Pusat Aplikasi Isotop, dan Radiasi, BATAN. Bahan lain yang digunakan selama penanaman adalah larutan pemutih yang mengandung $10 \%$ hipoklorit dan larutan pupuk cair. Pupuk cair yang digunakan adalah pupuk $\mathrm{AB}$ mix ${ }^{\circledR}$ yang dilarutkan ke dalam air bersih. $5 \mathrm{ml}$ larutan pupuk A dan $5 \mathrm{ml}$ larutan pupuk B dilarutkan dalam setiap 1 liter air bersih. Penggunaan larutan pupuk cair disesuaikan dengan kebutuhan pengairan harian

\section{Metode Eksperimen dan Analisis}

Penelitian ini menggunakan rancangan acak lengkap (RAL) dengan lima ulangan. Model statistik yang digunakan adalah: $Y \mathrm{ij}=\mu+\alpha \mathrm{i}+\varepsilon \mathrm{ij}$; dimana Yij adalah variabel terikat, $\mu$ adalah rerata perlakuan, $\alpha \mathrm{i}$ adalah pengaruh perbedaan varietas sorgum sedangkan eij adalah pengaruh acak/faktor error. Profil pertumbuhan, nutrisi, estimasi relative feed value (RFV) dan kecernaan in vitro adalah variabel yang diamati dalam penelitian ini. Perlakuan pada studi profil pertumbuhan, estimasi RFV dan nutrisi adalah: 1) $\mathrm{P}$ (sorgum varietas Pahat) sebagai varietas kontrol; 2) S1 (sorgum varietas Samurai 1); 3) S2 (sorgum varietas Samurai 2). Pada studi kecernaan in vitro menggunakan kontrol berupa rumput lapangan sehingga urutan perlakuannya adalah sebagai berikut: 1) RL (rumput lapangan); 2) P; 3) S1 dan 4) S2. Data yang diperoleh dianalisis dengan analisis ragam analysis of variance (ANOVA) dilanjutkan dengan uji Duncan's Multiple Range Test (Steel \& Torrie, 1980) pada taraf kepercayaan $95 \%$. Analisis statistik menggunakan bantuan perangkat SPSS 22.00.

\section{Penanaman Sorghum Green Fodder secara Hidroponik}

Penanaman sorghum green fodder (SGF) dilakukan pada instalasi hidroponik tipe nutrient film technique (Lee \& Lee, 2015) (Gambar 1). 


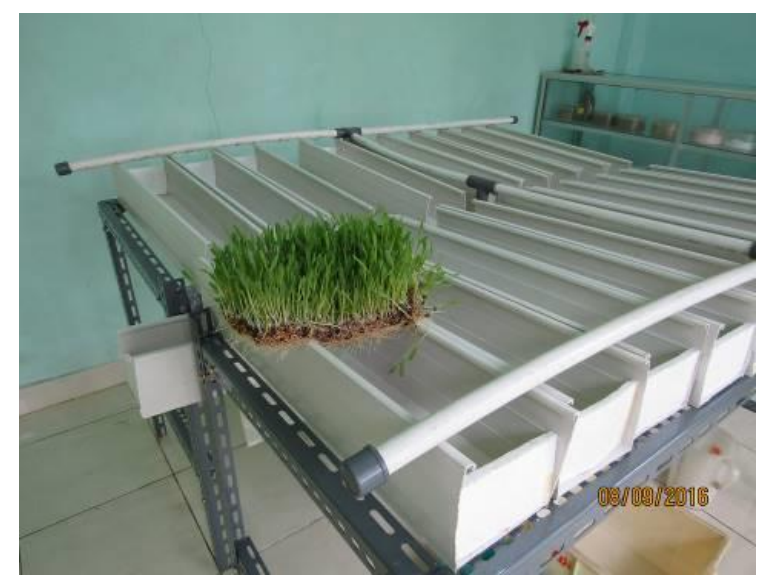

Gambar 1. Instalasi hidroponik tipe nutrient film technique untuk produksi sorghum green fodder (SGF)

Instalasi hidroponik dibuat mengguna-kan rak baja yang mampu menampung 20 rak berbahan polyethylene masing-masing berukuran $60 \times 18 \mathrm{~cm}$ (Gambar 1). Instalasi dihubungkan dengan sistem irigasi otomatis sebagai instrument pengairan. Instalasi hidroponik ditempatkan pada ruangan dengan suhu $20-22^{\circ} \mathrm{C}$ dan kelembaban $60-70 \%$. Biji sorgum yang telah dicuci kemudian direndam dalam air bersih selama 24 jam. Sterilisasi biji kemudian dilakukan menggunakan larutan hipoklorit (10\% larutan pemutih) untuk mencegah tumbuhnya jamur. Perendaman larutan hipoklorit dilakukan selama 20 menit kemudian dibilas dengan air bersih. Biji sorgum disebar pada rak dengan kerapatan $0,38 \mathrm{~g} / \mathrm{cm}^{2}$. Periode pengairan dilakukan selama dua menit setiap dua jam sekali menggunakan sistem irigasi otomatis. Rak plastik yang telah berisi biji sorgum ditutup plastik hitam pada hari pertama dan kedua untuk mendukung proses perkecambahan. Plastik dibuka pada hari ketiga sampai masa panen. Sorghum green fodder dipanen pada umur sembilan hari.

\section{Pengukuran Peubah}

\section{Profil pertumbuhan}

Pemanenan Sorghum green fodder dilakukan pada umur sembilan hari. Panen dilakukan pada seluruh bagian tanaman meliputi akar, batang dan daun (Gambar 2). Pengamatan studi profil pertumbuhan meliputi: berat segar (g), tinggi tanaman $(\mathrm{cm})$, rasio konversi (SGF:biji), kandungan bahan kering (BK) dan bahan organik (BO) setelah panen.

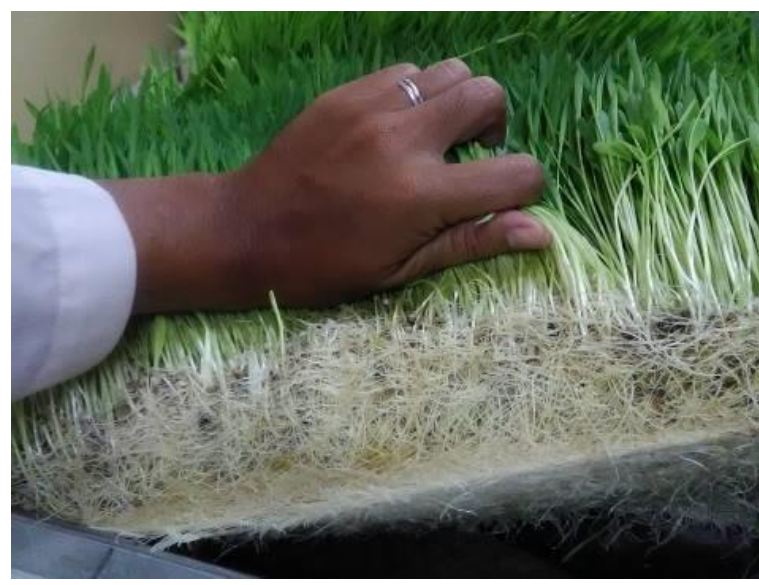

Gambar 2. Sorghum green fodder (SGF) pada umur panen sembilan hari

\section{Profil Nutrisi}

Sorghum green fodder dikeringkan pada suhu $60^{\circ} \mathrm{C}$ selama $48 \mathrm{jam}$. Sampel kering kemudian digiling dan disaring sampai berukuran $2 \mathrm{~mm}$. Pengamatan studi profil nutrisi meliputi: kandungan $\mathrm{BK}, \mathrm{BO}$, protein kasar (PK), lemak kasar (LK), neutral detergent fiber (NDF) dan acid detergent fiber (ADF). Analisis BK, BO dan LK menggunakan prosedur dalam AOAC (2010). Analisis PK menggunakan perangkat nitrogen alayzer. Pengukuran NDF dan ADF menggunakan metode dalam Goering \& Van Soest (1980). Kandungan NFC ditentukan dengan kalkulasi NFC $(\%)=\mathrm{BO}(\%)-\mathrm{PK}(\%)-\mathrm{NDF}(\%)-\mathrm{LK}(\%)$ (Kondo et al., 2015).

\section{Relative feed value (RFV)}

Penentuan estimasi RFV menggunakan kalkulasi berdasarkan Undersander et al. (1993). Nilai RFV diperoleh dari kalkulasi nilai estimasi $d r y$ matter intake (DMI) dan dry matter digestibility (DMD). Adapun perhitungannya adalah sebagai berikut:

$\operatorname{DMI}(\%$ berat badan $) \quad=\frac{120}{\% \mathrm{NDF}}$

$\operatorname{DMD}(\%) \quad=88,9-(\% \operatorname{ADF} \times 0,779)$

RFV $=\frac{\text { DMD } \times \text { DMI }}{1,29}$

Keterangan: 88,$9 ; 0,779 ; 120 ; 1,29$ adalah bilangan konstanta; NDF dan ADF berturut turut adalah kandungan neutral detergent fiber dan acid detergent fiber hijauan. 


\section{Kecernaan in vitro}

Prosedur yang digunakan adalah uji in vitro dua tahap Tilley \& Terry (1963). Cairan rumen yang digunakan berasal dari kerbau jantan berfistula yang diberi ransum pakan dengan perbandingan $70 \%$ rumput lapangan : $30 \%$ konsentrat (dalam BK). Parameter yang diamati adalah produk fermentasi rumen pada tahap pertama (inkubasi pada cairan rumen+buffer) dan kecernaan in vitro pada tahap kedua (penambahan pepsin dan $\mathrm{HCl}$ ). Produk fermentasi rumen seperti nilai $\mathrm{pH}$, konsentrasi $\mathrm{NH}_{3}$ (Conway, 1950) dan VFA total (Kroman et al., 1966) diamati pada proses fermentasi in vitro tahap pertama.

\section{HASIL DAN PEMBAHASAN}

\section{Profil Pertumbuhan}

SGF yang dipanen pada umur Sembilan hari dapat dilihat pada Gambar 2. Hasil pengamatan profil pertumbuhan SGF dapat dilihat pada Tabel 1. Rerata tinggi tanaman tertinggi dihasilkan oleh SGF varietas Samurai 2. SGF yang dihasilkan oleh varietas tersebut lebih tinggi 8,54\% dibandingkan Samurai 1 dan 23,12\% dibandingkan Pahat $(\mathrm{P}<0,05)$. SGF dari sorgum Samurai 2 juga menghasilkan berat panen segar yang lebih tinggi $42,86 \%$ dibandingkan varietas Pahat $(\mathrm{P}<0,05)$. Berat panen segar varietas Samurai 1 tidak berbeda nyata dibandingkan varietas Pahat. Produksi SGF juga dihitung berdasarkan nilai konversi SGF terhadap berat biji sebelum ditanam. Nilai konversi tertinggi juga dihasilkan oleh SGF Samurai 2. Nilai BO panen SGF Samurai 2 terlihat paling rendah $(\mathrm{P}<0,05)$ sedangkan nilai $\mathrm{BK}$ tidak berbeda nyata antar perlakuan.

Sorgum varietas Samurai 1 dan Samurai 2 menghasilkan biomassa SGF yang lebih besar dibandingkan varietas indukannya (Pahat). Hal tersebut dapat dilihat pada peubah berat panen segar, tinggi tanaman dan rasio konversi. Samurai 1 dan Samurai 2 merupakan hasil pemuliaan meng- gunakan teknik mutasi radiasi dari sorgum varietas Pahat (Wahyono et al., 2019a). Perbaikan varietas yang dilakukan salah satunya adalah dengan meningkatkan bimassa tanaman. Mutlu et al. (2015) melaporkan bahwa perbaikan varietas menggunakan teknik mutasi radiasi dengan sinar gamma dapat memperbaiki sifat morfologi tanaman pakan. Berbagai kelebihan berupa biomassa yang meningkat jika ditanam secara konvensional juga terlihat pada metode penanaman secara hidroponik. Hidayat et al. (2016) melaporkan bahwa varietas Samurai 2 berpotensi menghasilkan biomassa yang lebih tinggi dibandingkan Pahat dan Samurai 1. Dalam referensi yang sama juga dijelaskan bahwa varietas Pahat merupakan tipe sorgum yang pendek $( \pm 147,2 \mathrm{~cm})$ jika ditanam secara konvensional. Karakteristik tersebut juga terlihat pada cara penanaman secara hidroponik.

Berdasarkan Tabel 1, tinggi SGF berkisar antara 17,34-21,35 cm. Efendi et al. (2012) menjelaskan bahwa variasi tinggi tanaman yang berbeda antar varietas disebabkan oleh perbedaan karakteristik yang dikendalikan oleh faktor genetik dari masing-masing tanaman. Wahyono et al. (2019) melaporkan bahwa SGF Samurai 2 yang dipanen pada hari kesembilan dapat menghasilkan berat segar dan rasio konversi bertutur-turut sebesar $1,27 \mathrm{~kg}$ dan 6,31. Hasil tersebut cukup identik dengan produksi berat segar dan rasio konversi yang didapat dalam penelitian ini. Produksi SGF dan rasio konversi yang lebih rendah dihasilkan oleh Wahyono et al. (2019b). Dalam penelitian tersebut, SGF Samurai 2 menghasilkan berat segar dan rasio konversi berturut-turut sebesar $0.91 \mathrm{~kg}$ dan 4,24. Perbedaan tersebut dapat disebabkan oleh perlakuan sterilisasi biji sorgum sebelum ditanam. Wahyono et al. (2018) menggunakan sterilisasi radiasi 100-300 Gy, sedangkan Wahyono et al. $\left(2019^{\mathrm{b}}\right)$ menggunakan 5,25\% hipoklorit. Perbedaan tersebut diduga mempengaruhi proses germinasi, namun hal ini perlu diteliti lebih lanjut.

Tabel 1. Profil pertumbuhan sorghum green fodder (SGF) hasil penanaman secara hidroponik

\begin{tabular}{lllll}
\hline \multirow{2}{*}{\multicolumn{1}{c}{ Profil pertumbuhan }} & \multicolumn{3}{c}{ Varietas } \\
\cline { 2 - 4 } & Pahat & Samurai 1 & Samurai 2 & SEM \\
\hline Tinggi tanaman (cm) & $17,34^{\mathrm{a}}$ & $19,67^{\mathrm{b}}$ & $21,35^{\mathrm{c}}$ & 0,043 \\
Berat panen segar (kg/rak) & $0,84^{\mathrm{a}}$ & $0,91^{\mathrm{a}}$ & $1,20^{\mathrm{b}}$ & 0,429 \\
Konversi (SGF:biji) & $4,22^{\mathrm{a}}$ & $4,55^{\mathrm{a}}$ & $6,01^{\mathrm{b}}$ & 0,215 \\
Bahan kering (BK) panen (\%) & 9.68 & 9.78 & 11.04 & 0,232 \\
Bahan organik (BO) panen (\%) & $90,32^{\mathrm{b}}$ & $90,21^{\mathrm{b}}$ & $88,96^{\mathrm{a}}$ & 0,653
\end{tabular}

SGF : sorghum green fodder; Bahan kering panen diperoleh setelah SGF di kering anginkan dalam oven $60^{\circ} \mathrm{C}$; SEM : standard error of the means; superscript berbeda pada baris yang sama menunjukkan perbedaan yang nyata $(\mathrm{P}<0,05)$. 
Tinggi ketiga varietas SGF lebih rendah dibandingkan tinggi tanaman jagung yang ditanam secara hidroponik. Gebremedhin (2015) melaporkan bahwa rata-rata tinggi tanaman Maize Hidroponic Fodder (MHF) pada umur panen 8 hari berkisar $28 \mathrm{~cm}$. Naik et al. (2013) juga melaporkan bahwa MHF menghasilkan tinggi 20-30 cm pada umur panen yang sama. Nilai konversi (SGF:biji) penelitian ini berkisar antara 4,22-6,01. Nilai konversi memiliki pola yang sama dengan berat segar SGF. Hal tersebut karena produksi biomassa SGF varietas Samurai 2 lebih tinggi dibandingkan kedua varietas lainnya. Akan tetapi, nilai konversi tersebut masih lebih rendah dibandingkan jenis tanaman lainnya. Gebremedhin (2015) melaporkan bahwa MHF menghasilkan nilai konversi 8 pada umur panen 8 hari. Fazaeli et al. (2012) juga menjelaskan bahwa barley green fodder (BGF) yang dipanen pada umur 8 hari menghasilkan nilai konversi 7,21 . Perbedaan faktor konversi dapat dipengaruhi oleh faktor manajemen penanaman, jenis benih, kualitas benih, jumlah dan frekuensi irigasi (Hubballi et al., 2010).

\section{Profil Nutrisi}

Profil nutrisi SGF yang berasal dari tiga varietas sorgum dapat dilihat pada Tabel 2 . Kandungan BK dan ADF ketiga perlakuan tidak berbeda nyata. Kandungan BO pada profil nutrisi memiliki pola seperti kadar BO panen (Tabel 1) dimana varietas Samurai 2 mengandung nilai yang terendah $(\mathrm{P}<0,05)$. SGF Samurai 1 mengandung PK dan LK yang tertinggi dengan nilai masing-masing $19,26 \%$ dan 10,69\% ( $\mathrm{P}<0,05)$. Kandungan ADF tertinggi dihasilkan oleh perlakuan Samurai 2 yaitu lebih tinggi 50,60\% dibandingkan SGF varietas Pahat $(\mathrm{P}<0,05)$. SGF Pahat menghasilkan kandungan NFC yang tertinggi $(\mathrm{P}<0,05)$ namun tidak berbeda nyata dengan Samurai 2 .

Pola kandungan BO berbanding terbalik dengan profil pertumbuhan SGF (Tabel 1), dimana kadar BO SGF Samurai 2 terlihat paling rendah dibandingkan kedua varietas lain. Nilai BO ketiga SGF lebih tinggi jika dibandingkan dengan kadar BO tanaman sorgum yang ditanam secara konvesional yang berkisar pada 91,18\% (Wahyono et al., 2019a). Hal tersebut karena pada SGF dipanen pada umur panen 9 hari sehingga mengandung kandungan abu dan silika yang lebih rendah. Kandungan PK SGF berkisar antara 15,53-19,26\% dimana varietas Samurai 1 menghasilkan nilai yang tertinggi $(\mathrm{P}<0,05)$. Kandungan protein untuk bahan pakan ruminansia lebih kompleks penggunaannya. Hal tersebut disebabkan oleh pemenuhan kebutuhan protein yang masuk di usus halus berasal dari campuran protein pakan dan mikroba (Tilman et al., 1998). Kandungan PK SGF lebih tinggi dibandingkan kandungan PK barley hydroponic fodder yang berkisar 15\% (Fazaeli et al., 2012).

Kandungan ADF SGF Samurai 1 lebih rendah dibandingkan varietas Samurai 2. Hal ini dapat disebabkan oleh karakteristik sorgum Samurai 1 yang sebenarnya dimanfaatkan untuk produksi bioetanol. Tanaman tipe ini memerlukan fraksi karbohidrat struktural yang persentasenya lebih sedikit sebagai bahan pembuatan bioetanol (Wahyono et al., 2017). Kandungan NDF pada SGF sebagian besar disumbang oleh jalinan akar yang cukup dominan pada tanaman hydroponic fodder (Gambar 2). Hemiselulosa dan selulosa yang terdapat dalam fraksi NDF adalah tipe karbohidrat struktural yang merupakan sumber serat bagi mikroba rumen. Fraksi NDF memiliki korelasi yang kuat dengan konsumsi pakan yang dalam penelitian ini direpresentasikan dalam estimasi DMI (dibahas dalam sub bab berikutnya).

Kandungan ADF dan NFC adalah dua fraksi pakan yang merupakan indikator kecernaan suatu bahan pakan. fraksi NFC akan mudah didegradasi di dalam rumen sehingga mempercepat pembentukan energi ATP (adenosine triphosphate) untuk mikroba dan ternak. Fraksi ADF yang merepresentasikan lignin dan selulosa akan membutuhkan waktu yang lebih lama untuk didegradasi di dalam rumen. Hal tersebut akan menurunkan konversi energi dari tanaman kepada ternak. Fraksi ADF pada SGF Pahat lebih rendah dibandingkan kedua varietas lain $(\mathrm{P}<0,05)$. Hal tersebut sesuai dengan penelitian Wahyono et al. (2019a) yang menjelaskan bahwa sorgum Pahat adalah sorgum varietas mutan yang memiliki kandungan ADF yang rendah, terutama sebelum fase flowering.

Kandungan ADF pada SGF Samurai 2 adalah yang tertinggi $(32,59 \%, \mathrm{P}<0,05)$ dan nilainya sesuai dengan kisaran pada riset sebelumnya (Wahyono et al., 2018 \& Wahyono et al. 2019b). Kandungan ADF ketiga perlakuan SGF lebih rendah dibandingkan dengan rumput lapangan. Kondo et al. (2015) melaporkan bahwa rumput lapangan di daerah tropis mengandung fraksi $\mathrm{ADF}$ sekitar 38,8-43,6\%. Sorgum yang ditanam secara hidroponik menghasilkan ADF yang setara dengan maize hydroponic fodder (Nugroho et al., 2015), namun lebih tinggi dibandingkan barley green fodder (Fazaeli et al., 2012). Kandungan NDF dan ADF pada hijauan akan mempengaruhi estimasi RFV yang akan dibahas dalam sub bab berikutnya. 
Tabel 2. Profil nutrisi sorghum green fodder (SGF) hasil penanaman secara hidroponik

\begin{tabular}{lllll}
\hline \multicolumn{1}{c}{ Profil nutrisi (\%) } & \multicolumn{3}{c}{ Varietas } \\
\cline { 2 - 4 } & Pahat & Samurai 1 & Samurai 2 & SEM \\
\hline Bahan kering (BK) & 92,31 & 93,64 & 93,77 & 0,354 \\
Bahan organik (BO) & $95,10^{\mathrm{b}}$ & $95,29^{\mathrm{b}}$ & $94,15^{\mathrm{a}}$ & 0,196 \\
Protein kasar (PK) & $15,53^{\mathrm{a}}$ & $19,26^{\mathrm{c}}$ & $17,82^{\mathrm{b}}$ & 0,440 \\
Lemak kasar (LK) & $7,55^{\mathrm{a}}$ & $10,69^{\mathrm{b}}$ & $7,26^{\mathrm{a}}$ & 0,538 \\
Neutral detergent fiber (NDF) & 53,35 & 54,13 & 53,54 & 0,859 \\
Acid detergent fiber (ADF) & $21,64^{\mathrm{a}}$ & $26,39^{\mathrm{b}}$ & $32,59^{\mathrm{c}}$ & 1,391 \\
Non-fiber carbohydrate (NFC) & $18,66^{\mathrm{b}}$ & $11,71^{\mathrm{a}}$ & $15,75^{\mathrm{ab}}$ & 1,215 \\
\hline
\end{tabular}

SEM: standard error of the means; superscript berbeda pada baris yang sama menunjukkan perbedaan yang nyata $(\mathrm{P}<0,05)$.

\section{Relative Feed Value}

Estimasi DMI, DMD dan RFV pada SGF dapat dilihat pada Tabel 3. Estimasi ini dikalkulasi berdasarkan nilai NDF dan ADF pada hijauan pakan yang berpengaruh terhadap nilai konsumsi (DMI) dan kecernaannya (DMD). Estimasi RFV diperoleh dari estimasi utilisasi hijauan berdasarkan standar alfalfa. Undersander et al. (1993) menjelaskan bahwa estimasi RFV dapat diaplikasikan pada berbagai hijauan pakan seperti rumput, legum dan hay. Nilai DMD dan RFV tertinggi dihasilkan oleh SGF varietas Pahat. SGF Pahat yang memiliki nilai RFV 126,22 termasuk dalam kategori hijauan Premium berdasarkan Rohweder et al. (1978), sedangkan SGF Samurai 1 dan Samurai 2 termasuk dalam kategori Good .

Nilai RFV yang tinggi pada SGF Pahat merupakan representasi dari rendahnya kandungan ADF yang akan mempengaruhi nilai DMD (Tabel 3). Wahyono et al. (2019a) menjelaskan bahwa RFV berasosiasi dengan nilai utilitas nutrisi dan kualitas dari hijauan pakan. Hal tersebut membuktikan bahwa nilai pemanfaatan nutrisi SGF Pahat lebih tinggi dibandingkan Samurai 2. Estimasi RFV adalah estimasi relatif yang berbasis nilai nutrisi hijauan dengan kualitas tinggi yaitu alfalfa. Berdasarkan hal tersebut, perlu kalkulasi yang akurat dan absolut terkait estimasi hijauan pakan yang merepresentasikan nilai utilisasi nutrisi. Namun demikian, estimasi RFV masih layak digunakan untuk membandingkan utilitas nutrisi diantara satu komoditas hijauan. Rohweder et al. (1978) melaporkan bahwa perhitungan RFV hanya mempertimbangkan nilai konsumsi dan kecernaan pakan yang berdasarkan dari pakan sumber energi dan protein. Estimasi RFV belum merepresentasikan faktor utilisasi NFC dan golongan mikronutrien.

\section{Kecernaan In Vitro}

Hasil uji in vitro berupa kecernaan dan profil hasil fermentasi rumen dapat dilihat pada Tabel 4. Sampel rumput lapangan digunakan sebagai kontrol dalam pengujian ini. Kecernaan BK dan BO ketiga perlakuan SGF terlihat lebih tinggi dibandingkan rumput segar $(\mathrm{P}<0,05)$. SGF varietas Pahat cenderung menghasilkan kecernaan $\mathrm{BO}$ yang paling tinggi dengan nilai 62,68\%. SGF varietas Pahat dan Samurai 1 menghasilkan nilai $\mathrm{pH}$ yang lebih rendah $2,80 \%$ dan 2,52\% dibandingkan rumput lapangan $(\mathrm{P}<0,05)$. Nilai $\mathrm{pH}$ SGF Samurai 2 tidak berbeda nyata dibandingkan rumput lapangan. Perlakuan SGF varietas Samurai 2 menghasilkan produksi VFA total yang tertinggi dengan nilai 114,42 $\mathrm{mM}(\mathrm{P}<0,05)$. Konsentrasi $\mathrm{NH}_{3}$ yang dihasilkan keempat perlakuan tidak berbeda nyata.

Tabel 3. Estimasi relative feed value (RFV) sorghum green fodder (SGF) hasil penanaman secara hidroponik

\begin{tabular}{lllll}
\hline \multirow{2}{*}{ Profil nutrisi (\%) } & \multicolumn{3}{c}{ Varietas } & SEM \\
\cline { 2 - 4 } & Pahat & Samurai 1 & Samurai 2 & 0,039 \\
Dry matter intake (\% BB) & 2,25 & 2,25 & 2,28 & 1,227 \\
Dry matter digestibility (\%) & $72,69^{\mathrm{c}}$ & $68,10^{\mathrm{b}}$ & $63,64^{\mathrm{a}}$ & 2,781 \\
Relative feed value & $126,22^{\mathrm{b}}$ & $118,62^{\mathrm{ab}}$ & $112,45^{\mathrm{a}}$ & \\
\hline
\end{tabular}

SEM: standard error of the means; superscript berbeda pada baris yang sama menunjukkan perbedaan yang nyata $(\mathrm{P}<0,05)$. 
Tabel 4. Hasil uji in vitro sorghum green fodder (SGF) hasil penanaman secara hidroponik

\begin{tabular}{llllll}
\hline \multirow{2}{*}{\multicolumn{1}{c}{ Profil nutrisi }} & \multicolumn{5}{c}{ Varietas } \\
\cline { 2 - 5 } & $\begin{array}{l}\text { Rumput } \\
\text { lapangan }\end{array}$ & Pahat & Samurai 1 & Samurai 2 & SEM \\
\hline Kecernaan BK (\%) & $42,84^{\mathrm{a}}$ & $55,50^{\mathrm{b}}$ & $53,13^{\mathrm{b}}$ & $50,19^{\mathrm{b}}$ & 1,574 \\
Kecernaan BO (\%) & $51,27^{\mathrm{a}}$ & $62,68^{\mathrm{c}}$ & $58,60^{\mathrm{b}}$ & $57,73^{\mathrm{b}}$ & 1,332 \\
$\mathrm{pH}$ & $7,15^{\mathrm{b}}$ & $6,95^{\mathrm{a}}$ & $6,97^{\mathrm{a}}$ & $7,03^{\mathrm{ab}}$ & 0,027 \\
Konsentrasi $\mathrm{NH}_{3}(\mathrm{mg} / 100 \mathrm{ml})$ & 5,54 & 5,74 & 5,54 & 6,13 & 0,116 \\
Produksi VFA total $(\mathrm{mM})$ & $71,64^{\mathrm{a}}$ & $88,02^{\mathrm{b}}$ & $80,19^{\mathrm{b}}$ & $114,42^{\mathrm{c}}$ & 3,873 \\
\hline
\end{tabular}

BK: bahan kering; BO: bahan organik; $\mathrm{NH}_{3}$ : amoniak; VFA: volatile fatty acid; SEM: standard error of the means; superscript berbeda pada baris yang sama menunjukkan perbedaan yang nyata $(\mathrm{P}<0,05)$.

Kecernaan BO SGF Pahat cenderung lebih tinggi dibandingkan kedua perlakuan SGF lain. Hal tersebut dapat disebabkan oleh kandungan ADF yang lebih rendah (Tabel 2) sehingga proses degradasi fraksi serat menjadi lebih cepat. Fraksi NFC pada SGF Pahat juga cenderung lebih tinggi sehingga utilisasi energi cenderung lebih cepat. Kondo et al. (2015) melaporkan bahwa fraksi NFC adalah golongan karbohidrat yang mudah difermentasi sehingga akan berasosiasi positif dengan kecernaan yang tinggi. Kecernaan BO SGF Pahat yang tinggi juga sejalan dengan nilai estimasi RFV yang tinggi. Hal ini membuktikan bahwa estimasi RFV berasosiasi positif dengan kecernaan BO hijauan pakan. Kecernaan in vitro ketiga perlakuan SGF terlihat lebih tinggi dibandingkan rumput lapangan. Kecernaan BO merupakan representasi dari optimalnya kondisi fermentasi rumen. Wajizah et al. (2015) melaporkan bahwa kecernaan pakan sering digunakan sebagai indikator kualitas suatu bahan pakan.

Nilai $\mathrm{pH}$ keempat perlakuan cenderung dalam kondisi netral sesuai dengan $\mathrm{pH}$ ekosistem rumen. Nilai $\mathrm{pH}$ yang tidak stabil akan menyebabkan terganggunya aktivitas mikroba rumen yang menyebabkan penurunan tingkat kecernaan nutrien pakan. Produksi VFA total keempat perlakuan tergolong tinggi. Chantakoun \&Wanapat (2012) melaporkan bahwa produksi VFA total pada rumen kerbau rawa yang diberi pakan jerami sorgum berkisar 53,3 mM. Tingginya nilai VFA total berasosiasi dengan tingginya pemanfaatan fraksi sumber energi berupa NFC dan NDF. Dengan kata lain, ketiga perlakuan SGF dapat lebih mendukung ekosistem mikroba rumen dibandingkan rumput lapangan.

\section{KESIMPULAN}

Sorgum varietas Samurai 2 yang ditanam secara hidroponik menghasilkan berat segar, tinggi tanaman dan rasio konversi (SGF:biji) terbaik dibandingkan kedua varietas lain. SGF dari sorgum Samurai 1 menghasilkan kandungan PK dan LK kasar tertinggi. SGF dari varietas Pahat menghasilkan fraksi ADF terendah yang berpengaruh terhadap kecernaan $\mathrm{BO}$ yang tinggi. Profil kecernaan in vitro SGF dari ketiga varietas sorgum lebih tinggi dibandingkan rumput lapangan. Sorgum Samurai 2 adalah varietas yang direkomendasikan untuk menghasilkan produksi biomassa tinggi jika ditanam secara hidroponik. Sorgum pahat adalah varietas yang direkomendasikan untuk menghasilkan profil nutrisi hidroponik yang tinggi, sehingga dapat dikaji sebagai sumber pakan fungsional

\section{UCAPAN TERIMAKASIH}

Penelitian ini didanai oleh Daftar Isian Penggunaan Anggaran (DIPA) laboratorium Nutrisi Ternak, Bidang Pertanian, Pusat Aplikasi Isotop dan Radiasi BATAN. Penulis mengucapkan terima kasih kepada seluruh staf laboratorium nutrisi ternak PAIR BATAN yang telah membantu proses penelitian.

\section{DAFTAR PUSTAKA}

Akbag, H.I., O.S. Turkmen, H. Baytekin, \& I.Y. Yurtman. 2014. Effects of harvesting time on nutritional value of hydroponic barley production. Turk. J. Agri. Nat. Sci. Special issue 2:1761-1765.

AOAC. 2010. Official methods of analysis of AOAC. 18th Ed, Maryland.

Budiarsana I.G.M., Ashari, E. Juarini, \& B. Wibowo. 2009. Potensi dan kesesuaian wilayah untuk peternakan sapi potong di perkotaan (studi kasus kecamatan Kuranji kota Padang). Prosiding Seminar Nasional Teknologi Peternakan dan Veteriner. Pusat Penelitian dan Pengembangan Peternakan. Bogor. 13-14 Agustus 2009. Hlm. 340-348. 
Chanthakhoun, V., \& M. Wanapat. 2012. The in vitro gas production and ruminal fermentation of various feeds using rumen liquor from swamp buffalo and cattle. Asian J Anim Vet Adv 7:54-60.

Conway E.J. 1950. Micro-diffusion Analysis and Volumetric Error. Lockwood, London.

Efendi, Halimursyadah, \& H.R. Simajuntak. 2012. Respon Pertumbuhan dan Produksi Plasma Nutfah Padi Lokal Aceh Terhadap Sistem Budidaya Aerob. Jurnal Agrista 16:114-121.

Fazaeli, H., H.A. Golmohammadi, S.N. Tabatabayee, \& Asghari-Tabrizi. 2012. Productivity and nutritive value of barley green fodder yield in hydroponic system. World App Sci J 16: 531-539.

Gebremedhin, W.K. 2015. Effect of Growing Media on Nutrient Profile of Conventional and Hydroponic Maize Fodder. Int J Sci Res 4:223-225.

Ghazi N, Al-Karaki, \& Al-Momani. 2011. Evaluation of some barley cultivars for green fodder production and water use efficiency under hydroponic conditions. Jordan J Agric Sci 7: 448-457.

Goering, H. K. \& P. J. Van Soest. 1970. Forage Fibre Analysis (apparatus, reagents, procedures, and some application). Agric. handbook 379, ARS., USDA. Washington, DC.

Hubballi, M.S., T. Nakkeeran. T. Raguchander, R. Anand, \& Samiyappan. 2010. Effect of Environmental conditions on growth of alternaria alternata causing leaf blight of noni. World J Agri Sci 6:171-177.

Kondo, M., M. Yoshida, M. Loresco, R.M. Lapitan, J.R.V. Herrera, N. Del Barrio, Y. Uyeno, H. Matsui, \& T. Fujihara. 2015. Nutrient contents and in vitro ruminal fermentation of tropical grasses harvested in wet season in the Philippines. Adv Anim Vet Sci 3: 694-699.

Kromann, R.P., J.H. Meyer, \& W.J. Stielau. 1966. Steam distillation of volatile fatty acids in rumen ingesta. J Dairy Sci 50: 73-76.

Lee, S. \& J. Lee. 2015. Beneficial bacteria and fungi in hydroponic systems: Types and characteristics of hydroponic food production methods. Sci Hort 195: 206-215.

Mutlu, S.S., H. Djapo, S.F. Ozmen, C. Selim, \& N. Tunce. 2015. Gamma-ray Irradiation Induces
Useful Morphological Variation in Bermudagrass. Not Bot Horti Agrobo 43:515-520.

Naik, P.K., S.P. Gaikwad, M.J. Gupta, R.B. Dhuri, G.M. Dhumal, \& N.P. Singh. 2013. Low cost devices for hydroponics fodder production. Indian Dairyman 65:68-72.

Nugroho, H.D., I. G. Permana, \& Despal. 2015. Utilization of bioslurry on maize hydroponic fodder as a corn silage supplement on nutrient digestibility and milk production of dairy cows. Med Pet 38:70-76.

Rohweder, D.A., R.F. Barnes \& N. Jorgensen. 1978. Proposed hay grading standards based on laboratory analyses for evaluating quality. $\mathrm{J}$ Anim Sci 47:747-759.

Saidi, A.R.M.A., \& J. A. Omar. 2015. The biological and economical feasibility of feeding barley green fodder to lactating awassi ewes. Open J Anim Sci 5:99-105.

Sihono, S. Human, W.M. Indriatama, W. Puspitasari, Parno, \& Carkum. 2013. Galur Mutan Sorgum PATIR-1 Berdaya Hasil Biji, Biomasa dan Gula Batang Tinggi serta Galur PATIR-4 Hasil Biji Tinggi Kualitas Baik. Perbaikan Proposal Pelepasan Varietas. Pusat Aplikasi Isotop dan Radiasi BATAN, Jakarta.

Steel, R.G.D., \& J.H. Torrie. 1980. Principles and Procedures of Statistics, $2^{\text {nd }}$ ed. McGrawHill, New York.

Sumanto, \& E. Juarini. 2004. Potensi kesesuaian lahan untuk pengembangan ternak ruminansia di propinsi Nusa Tenggara Timur. Prosiding Seminar Nasional Teknologi Peternakan dan Veteriner. Pusat Penelitian dan Pengembangan Peternakan. Bogor. 29 Mei 2004. Hlm. 123-129.

Tilley, J.M.A., \& R.A. Terry. 1963. A two stage techniques for the in vitro digestion of forage crops. J British Grassl Soc 18:104-111.

Tilman, A.D., H. Hartadi, S. Reksohadiprojo, S. Prawirokusumo, \& Lebdosokojo. 1998. Ilmu Makanan Ternak Dasar. UGM Press. Yogyakarta.

Undersander, D., D.W. Mertens, \& N. Theix. 1993. Forage Analysis Procedures. National Forage Testing Association. Omaha.

Wahyono, T., N. Lelananingtyas, \& Sihono. 2017. Effects of gamma irradiation on ruminal 
degradation of Samurai 1 Sweet Sorghum Bagasse. Atom Indonesia 43: 35-39.

Wahyono, T., S.N.W. Hardani, \& I. Sugoro. 2018. Low irradiation dose for sorghum seed sterilization: hydroponic fodder system and in vitro study. Buletin Peternakan 42:215221.

Wahyono, T., I. Sugoro, A. Jayanegara, K.G. Wiryawan, \& D.A. Astuti. 2019a. Nutrient profile and in vitro degradability of new promising mutant lines sorghum as forage in Indonesia. Adv Anim Vet Sci 7:810-818.

Wahyono, T., H. Khotimah, W. Kurniawan, D. Ansori, \& A. Muawanah. 2019b. Karakteristik tanaman sorghum green fodder (SGF) hasil penanaman secara hidroponik yang dipanen pada umur yang berbeda.
Jurnal Ilmu dan Teknologi Peternakan Tropis $6(2): 166-174$.

Wajizah, S., Samadi, Y. Usman, \& E. Mariana. 2015. Evaluasi nilai nutrisi dan kecernaan in vitro pelepah kelapa sawit (oil palm fronds) yang difermentasi menggunakan Aspergillus niger dengan penambahan sumber karbohidrat yang berbeda. Agripet 15(1):1319.

Zahera, R., I.G. Permana, \& Despal. 2015. Utilization of mungbean's green house fodder and silage in the ration for lactating dairy cows. Med Pet 38:123-131. 